\title{
NEW SPECIES OF YEASTS FOUND IN JAPAN
}

\author{
TAKASHI NAKASE
}

Central Research Laboratories, Ajinomoto Co., Inc., Kawasaki 210, Japan

(Received May 25, 1971)

\begin{abstract}
From the yeasts collected from various natural habitats in Japan from April 1962 to May 1965, six new species, Candida fibrae, Candida fragicola, Torulopsis auriculariae, Torulopsis fructus, Torulopsis musae, and Trichosporon brassicae, were found. DNA base composition of these new species was calculated from the thermal denaturation temperature of DNA and used for confirmation of identification.
\end{abstract}

Through the investigation on wild yeasts in Japan, 8 strains of hitherto undescribed yeasts were isolated and classified into 6 species on the basis of criteria commonly employed in the yeast taxonomy and from the GC content in DNA. This paper describes these new species.

\section{MATERIALS AND METHODS}

Isolation of yeasts. Yeasts were isolated from various sources using yeast extract-malt extract (YM) agar plates and purified by the conventional streaking technique.

Determination of yeasts. Determinative methods are mainly those reported by WICKERHAM (1) and by LODDER and KREGER-VAN RIJ (2). Vitamin requirement and maximum growth temperature were determined by the method previously described (3). Urease was detected by the method of SEELIGER (4).

Determination of DNA base composition. DNAs were isolated and purified by the procedure previously reported (5). DNA base composition was calculated from the thermal denaturation temperature $(\mathrm{Tm})$ of DNA using the formula of MARMUR and DOTY (6). Tm was measured by the apparatus described by YAMADA and KOMAGATA (7).

\section{RESULTS AND DISCUSSION}

1). Candida fibrae NAKASE sp. nov.

Strain: AJ 4792

In musto maltato cellulae rotundae, ovoideae, cylindratae aut longae, 
$(2.5-7) \times(3-7-60) \mu$, singulae, binae aut catenatae. Sedimentum et anulus formantur. Cultura in agaro maltato (post unum mensem, $17^{\circ}$ ) flavoalbida aut albida, plana aut elevata, rigida, hirsuta, margine pilosa. Mycelium plena formatur. D-Glucosum, D-galactosum (tarde), saccharosum, maltosum (tarde et exiguum), raffinosum (tarde) et trehalosum (lente) fermentantur at non melibiosum, melezitosum, inulinum nec amylum. In medio minerali Dglucosum, G-galactosum, saccharosum, maltosum, cellobiosum, trehalosum, raffinosum, amylum, D-xylosum, L-arabinosum, D-ribosum, ethanolum, glycerolum, erythritolum, adonitolum, D-mannitolum, D-sorbitolum, $\alpha$-methyl-Dglucosidum, salicinum, potassium gluconatum, calcium 2-ketogluconatum, acidum succinicum et acidum citricum assimilantur at non lactosum, L-sorbosum, melibiosum, melezitosum, inulinum, D-arabinosum, L-rhamnosum, dulcitolum, acidum DL-lacticum nec inositolum. Nitras kalicus non assimilatur. Arbutinum finditur. Vitaminae externae non necessariae ad crescentiam. Maxima temperatura crescentiar: $37-38^{\circ}$.

Growth in malt extract: After 3 days at $25^{\circ}$, cells are round, oval, cylindrical, or elongate, $(2.5-7) \times(3-7-60) \mu$, and occur singly, in pairs, or in pseudomycelia. Many hyphal fragments are observed. A sediment and a trace of ring are formed. After one month at $17^{\circ}$, a thin ring and a sediment are present.

Growth on malt agar: After 3 days at $25^{\circ}$, true mycelia are exclusively formed. After one month at $17^{\circ}$, the streak culture is yellowish white to white, hairly all over the surface, partly wrinkled, tough, and has a ciliate margin.

Slide culture: True mycelia develop abundantly. Papillated hyphae are often observed. Blastospores are round to oval, in chains or in clusters.

Fermentation: D-Glucose, D-galactose (slow), saccharose, maltose (slow and weak), raffinose (slow), and trehalose (latent) are fermented. Melibiose, melezitose, inulin, and soluble starch are not fermented.

Assimilation of carbon compounds: D-Glucose, D-galactose, saccharose, maltose, cellobiose, trehalose, raffinose, soluble starch, D-xylose, L-arabinose, D-ribose, ethanol, glycerol, erythritol, adonitol, D-mannitol, D-sorbitol, $\alpha$ methyl-D-glucoside, salicin, potassium gluconate, calcium 2-keto-gluconate, succinic acid, and citric acid are assimilated. Lactose, L-sorbose, melibiose, melezitose, inulin, D-arabinose, L-rhamnose, dulcitol, DL-lactic acid, and inositol are not assimilated.

Potassium nitrate is not utilized as the sole nitrogen source.

Arbutin is splitted.

Gelatin is liquefied.

Starch-like compounds are not produced.

Maximum growth temperature is $37-38^{\circ}$.

Vitamin is not required for growth at $25^{\circ}$.

Urease is not detected on Christensen's medium.

Source: Banana, food market, Tokyo, May 1962. 


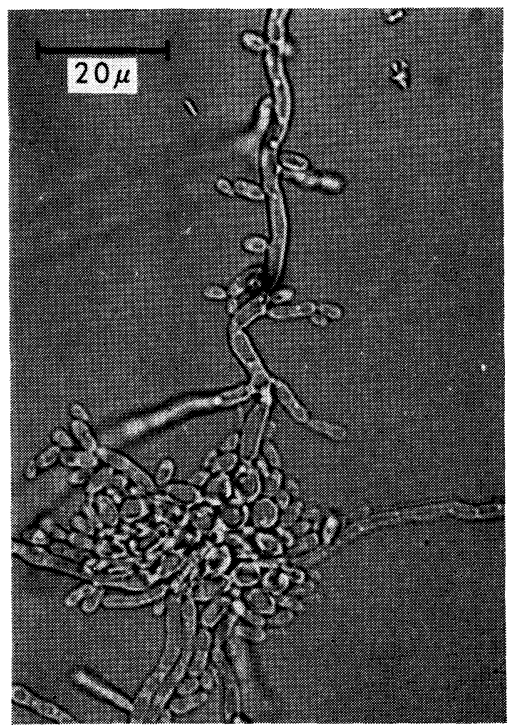

Fig. 1. True mycelia of Candida fibrae AJ 4792, slide culture on potato dextrose agar for 7 days at $25^{\circ}$.

This species forms abundant well-developed true mycelia and ferments a considerable number of sugars, and resembles Candida tropicalis in these respects, but differs from it because it assimilates raffinose, D-ribose, erythritol, ferments raffinose, liquefies gelatin, requires no vitamin, and has a lower maximum growth temperature than that reported for Candida tropicalis (8). The GC content in DNA of this species is $36.3 \%$ (Table 1) which is similar to that of Candida tropicalis (9). These facts suggest a close relationship between Candida fibrae and Candida tropicalis. The specific epithet "fibrae" was derived from the Latin "fibra" meaning "fiber" which indicates the morphological characteristic of this species. The strain AJ 4792 is the type strain of this species, and was deposited in the Fermentation Research Institute, Agency of Industrial Science and Technology, Inage, as FERM-P No. 889.

2). Candida fragicola NAKASE $s p$. nov.

Strain: AJ 4730

In medio liquido cellulae ovoideae, long ovoideae aut longae, $(2-3.5) \times$ (3.5-30) $\mu$, singulae, binae aut catenatae. Pellicula formatur (post unum mensem, $17^{\circ}$ ). Cultura in agaro flavoglauca, rugosa, margine pilosa. Pseudomycelium formatur. D-Glucosum et D-galactosum fermentantur at non saccharosum, maltosum, lactosum, raffinosum nec melibiosum. In medio minerali D-glucosum, D-galactosum, cellobiosum, amylum, D-xylosum, L-arabinosum, 
Table 1. DNA base composition of new species of yeasts.

\begin{tabular}{l|c|c|c}
\hline \multicolumn{1}{c|}{ Species } & Strain & $\begin{array}{c}\text { Tm } \\
\left({ }^{\circ} \mathrm{C}\right)\end{array}$ & $\begin{array}{c}\text { GC content } \\
(\text { mole \% })\end{array}$ \\
\hline Candida fibrae & AJ 4792 & 84.2 & 36.3 \\
Candida fragicola & AJ 4730 & 83.5 & 34.6 \\
Torulopsis auriculariae & AJ 4404 & 91.6 & 54.4 \\
Torulopsis fructus & AJ 4401 & 89.3 & 48.8 \\
"I & AJ 4402 & 89.2 & 48.5 \\
Torulopsis musae & AJ 4408 & 88.9 & 47.8 \\
Trichosporon brassicae & AJ 4833 & 91.8 & 54.9 \\
Calf thymus & & $86.5 \pm 0.2$ & $42.0 \pm 0.5$ \\
\hline
\end{tabular}

ethanolum, glycerolum, adonitolum, D-mannitolum (lente), D-sorbitolum (lente), salicinum, potassium gluconatum, acidum DL-lacticum, acidum succinicum, et inositolum assimilantur at non saccharosum, maltosum, lactosum, L-sorbosum, trehalosum, melibiosum, raffinosum, melezitosum, inulinum, D-arabinosum, D-ribosum, L-rhamnosum, erythritolum, dulcitolum, $\alpha$-methyl-D-glucosidum, calcium 2-ketogluconatum nec acidum citricum. Nitras kalicus non assimilatur. Arbutinum finditur (exiguum). Biotinae et thiaminae necessariae ad crescentiam. Maxima temperatura crescentiar: $34-35^{\circ}$.

Growth in YM broth: After 3 days at $25^{\circ}$, cells are oval to long oval or elongate, $(2-3.5) \times(3.5-30) \mu$, and occur singly, in pairs, or in chains. Islets and a sediment are formed. After one month at $17^{\circ}$, a thick pellicle is present.

Growth on YM agar: After one month at $17^{\circ}$, the streak culture is yellowish gray, delicately wrinkled, and has a ciliate margin.

Slide culture: Pseudomycelia are formed abundantly. Pseudomycelial cells are slender. Blastospores are usually long oval or elongate, and occur singly or in chains.

Fermentation: D-Glucose and D-galactose are fermented. Saccharose, maltose, lactose, raffinose, and melibiose are not fermented.

Assimilation of carbon compounds: D-Glucose, D-galactose, cellobiose, soluble starch, D-xylose, L-arabinose, ethanol, glycerol, adonitol, D-mannitol (latent), D-sorbitol (latent), salicin, potassium gluconate, DL-lactic acid, succinic acid, and inositol are assimilated. Saccharose, maltose, lactose, L-sorbose, trehalose, melibiose, raffinose, melezitose, inulin, D-arabinose, D-ribose, Lrhamnose, erythritol, dulcitol, $\alpha$-methyl-D-glucoside, calcium 2-ketogluconate, and citric acid are not assimilated.

Potassium nitrate is not utilized as the sole nitrogen source.

Arbutin is weakly splitted.

Gelatin is not liquefied.

Starch-like compounds are not produced. 


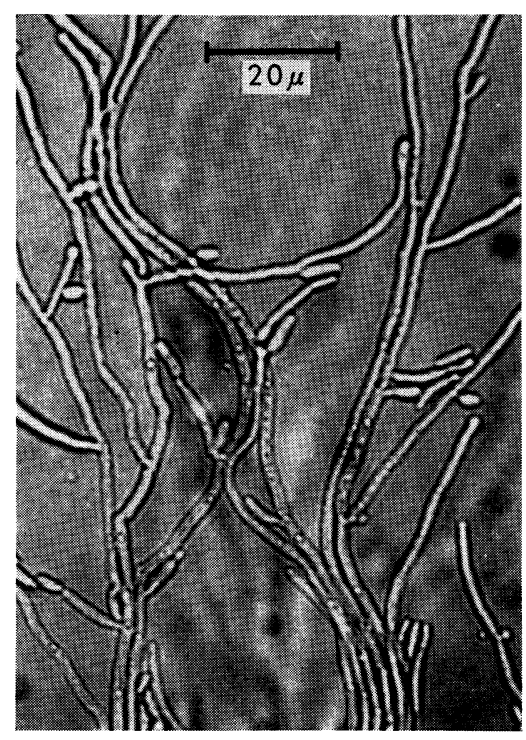

Fig. 2. Pseudomycelia of Candida fragicola AJ 4730, slide culture on potato dextrose agar for 7 days at $25^{\circ}$.

Maximum growth temperature is $34-35^{\circ}$.

Biotin and thiamine are required at $25^{\circ}$.

Source: Strawberry, food market in Tokyo, April 1962.

This yeast resembles Candida norvegensis, Candida conglobata, and Candida catenulata. Candida fragicola, however, differed from Candida norvegensis in the assimilation of D-galactose, soluble starch, D-xylose, L-arabinose, adonitol, $\mathrm{D}$-mannitol, D-sorbitol, and inositol, in maximum growth temperature, and in requirement of pyridoxine $(8)$ in spite of a close similarity in the GC content (9). It also differs from Candida conglobata in the assimilation of L-sorbose, trehalose, soluble starch, D-arabinose, D-ribose, erythritol, DL-lactic acid, and calcium 2-ketogluconate (NAKASE and KomAGATA, unpublished data). The GC content of Candida fragicola is $34.6 \%$ (Table 1) which is about $19 \%$ lower than that of Candida catenulata (9), so that this yeast is not related to Candida catenulata. The specific epithet is derived from the Latin "fragum" meaning "strawberry", and "colo" meaning "inhabit" since it was isolated from strawberry. The strain AJ 4730 is the type strain of this species, and was deposited in the Institute for Fermentation, Osaka, as IFO 1574.

3). Torulopsis auriculariae NAKASE sp. nov.

Strains: AJ 4404 and AJ 4405

In medio liquido cellulae subovoideae aut ovoideae, $(3-4.5) \times(4-7) \mu$, 
singulae aut binae. Sedimentum formatur. Cultura in agaro flavoalbida, accliva aut pulvinata, lena, nitida, mucosa, margine glabra. Pseudomycelium non formatur. Fermentatio nulla. In medio minerali D-glucosum, saccharosum, maltosum (varium), trehalosum (lente), melezitosum, ethanolum, glycerolum, D-mannitolum, D-sorbitolum (exiguum), acidum gluconicum et calcium 2-ketogluconatum assimilantur at non D-galactosum, lactosum, L-sorbosum, cellobiosum, melibiosum, raffinosum, inulinum, amylum, D-xylosum, L-arabinosum, D-arabinosum, D-ribosum, L-rhamnosum, erythritolum, adonitolum, dulcitolum, $\alpha$-methyl-D-glucosidum, salicinum, acidum DL-lacticum, acidum succinicum, acidum citricum nec inositolum. Nitras kalicus non assimilatur. Arbutinum non finditur. Amylum non formatur. Pyridoxinae et thiaminae necessariae ad crescentiam. Maxima temperatura crescentiar: 28-29.

Growth in YM broth: After 3 days at $25^{\circ}$, cells are short oval to oval, (3-4.5) $\times(4-7) \mu$, and occur singly or in pairs. Sometimes elongated cells are observed. Only a sediment is formed. After one month at $15^{\circ}$, a ring is also formed.

Growth on YM agar: After one month at $15^{\circ}$, the streak culture is yellowish white to yellowish gray, raised to pulvinate, smooth, shining, mucous to fluid, and has an entire margin.

Slide cultures and Dalmau plate cultures: No pseudomycelium is formed.

Fermentation: Absent.

Assimilation of carbon compounds: D-Glucose, saccharose, trehalose (latent), melezitose, ethanol, glycerol, D-mannitol, D-sorbitol (weak), potassium gluconate, and calcium 2-ketogluconate are assimilated. Maltose is utilized latently or not utilized. D-Galactose, lactose, L-sorbose, cellobiose, melibiose, raffinose, inulin, soluble starch, D-xylose, L-arabinose, D-arabinose, D-ribose, L-rhamnose, erythritol, dulcitol, $\alpha$-methyl-D-glucoside, salicin, DL-lactic acid, succinic acid, citric acid, and inositol are not utilized.

Potassium nitrate is not utilized as the sole nitrogen source.

Arbutin is not splitted.

Gelatin is not liquefied.

Starch-like compounds are not produced.

Maximum growth temperature is $28-29^{\circ}$.

Pyridoxine is essentially and thiamine is stimulatively required at $25^{\circ}$.

Urease activity: Strongly positive on Christensen's medium.

Source: Fruiting body of Auricularia auricula-judae, collected in Zaruga-take (Mt. Zaru), Yamanashi Prefecture, May 1965.

This yeast is asporogenous, forms no pseudo- or true mycelium, does not form manifest carotenoid pigment, and has short oval to oval cells. Further, it does not assimilate inositol and produces no starch in spite of a mucous appearance of the colony. This suffices the delimitation of the genus Torulopsis BERLESE (10). This yeast is assumed to be related to heterobasidiomycetes since it has a high GC content in DNA (Table 1) and shows a strong urease 
activity on Christensen's medium. The name Torulopsis auriculariae is proposed for this new yeast since it was isolated from a fruiting body of Auricularia auricula-judae. The strain AJ 4404 is the type strain of this species, and was deposited in the Institute for Fermentation, Osaka, as IFO 1580.

\section{4). Torulopsis fructus NAKASE sp. nov.}

Strains: AJ 4401 and AJ 4402

In medio liquido cellulae rotundae aut subovoideae, $(1.5-6.5) \times(2-7) \mu$, singulae aut binae. Sedimentum et anulus formantur. Cultura in agaro (post unum mensum, $17^{\circ}$ ) subflava aut flavoglauca, plana aut elevata, mollis, grabla, margine glabra. Pseudomycelium nullum. D-Glucosum et trehalosum (lente) fermentantur at non D-galactosum, saccharosum, maltosum, lactosum, raffinosum, melibiosum, melezitosum, inulinum nec amylum. In medio minerali D-glucosum, L-sorbosum, trehalosum, D-xylosum, ethanolum, glycerolum, adonitolum, D-mannitolum, D-sorbitolum, potassium gluconatum (lente), calcium 2-ketogluconatum, acidum succinicum et acidum citricum assimilantur at non D-galactosum, saccharosum, maltosum, lactosum, cellobiosum, melibiosum, raffinosum, melezitosum, inulinum, amylum, L-arabinosum, D-arabinosum, D-ribosum, L-rhamnosum, erythritolum, dulcitolum, $\alpha$-methyl-D-glucosidum, salicinum, acidum DL-lacticum nec inositolum. Nitras kalicus non assimilatur. Arbutinum non finditur. Biotinae et pyridoxinae necessariae ad crescentiam. Maxima temperatura crescentiar: $36-37^{\circ}$.

Growth in YM broth: After 3 days at $25^{\circ}$, cells are nearly round to short oval, $(1.5-6.5) \times(2-7) \mu$, and occur singly or in pairs. A thin ring and a sediment are formed. After one month at $17^{\circ}$, a ring and a sediment are present.

Growth on YM agar: After one month at $17^{\circ}$, the streak culture is pale yellow to pale yellowish brown, flat to raised, soft, smooth or almost smooth, and has an entire margin.

Slide culture: No pseudomycelium is formed.

Fermentation: D-Glucose and trehalose (latent) are fermented. D-Galactose, saccharose, maltose, lactose, raffinose, melibiose, melezitose, inulin, and soluble starch are not fermented.

Assimilation of carbon compounds: D-Glucose, L-sorbose, trehalose, Dxylose, ethanol, glycerol, adonitol, D-mannitol, D-sorbitol, potassium gluconate (latent), calcium 2-ketogluconate, succinic acid, and citric acid are assimilated. D-Galactose, saccharose, maltose, lactose, cellobiose, melibiose, raffinose, melezitose, inulin, soluble starch, L-arabinose, D-arabinose, D-ribose, L-rhamnose, erythritol, dulcitol, $\alpha$-methyl-D-glucoside, salicin, DL-lactic acid, and inositol are not assimilated.

Potassium nitrate is not utilized as the sole nitrogen source.

Arbutin is not splitted.

Gelatin is not liquefied.

Starch-like compounds are not produced. 
Maximum growth temperature is $36-37^{\circ}$.

Biotin and pyridoxine are required at $25^{\circ}$.

Urease is not detected on Christensen's medium.

Source: Banana, food market in Tokyo, May 1962.

In the taxonomic criteria commonly employed, this yeast resembles Torulopsis castellii and Torulopsis glabrata. Differing from the standard description of Torulopsis castellii (10), however, this yeast assimilates L-sorbose, D-xylose, ethanol, adonitol, D-mannitol, D-sorbitol, succinic acid, and citric acid, and requires biotin and pyridoxine but not inositol, niacin, or thiamine. The GC content in DNA of Torulopsis fructus is $48.5-48.8 \%$ (Table 1) which is about $10 \%$ higher than that of Torulopsis glabrata (11) and, therefore, similarity found between these two species is apparent but not real. The specific epithet is derived from the Latin "fructus" meaning "fruit" from which this species was isolated. The strain AJ 4401 is the type strain of this species, and was deposited in the Institute for Fermentation, Osaka, as IFO 1581.

\section{5). Torulopsis musae NAKASE $s p$. nov.}

Strain: AJ 4408

In medio liquido cellulae rotundae aut ovoideae, $(2-5.5) \times(2.5-7) \mu$, singulae, binae aut catenatae. Sedimentum formatur. Cultura in agaro (post unum mensem, $17^{\circ}$ ) flavoglauca, plana, glabra, nitida, mollis, margine glabra. Pseudomycelium nullum. D-Glucosum et trehalosum (lente) fermentantur at non D-galactosum, saccharosum, maltosum, lactosum, raffinosum, melibiosum, melezitosum, inulinum nec amylum. In medio minerali D-glucosum, saccharosum, maltosum, L-sorbosum, trehalosum, melezitosum, D-xylosum, Dribosum (lente), L-rhamnosum (lente), ethanolum, glycerolum, adonitolum, D-mannitolum, D-sorbitolum, $\alpha$-methyl-D-glucosidum (lente), potassium gluconatum, calcium 2-ketogluconatum, acidum succinicum, et acidum citricum assimilantur at non D-galactosum, lactosum, cellobiosum, melibiosum, raffinosum, inulinum, amylum, L-arabinosum, D-arabinosum, erythritolum, dulcitolum, salicinum, acidum DL-lacticum nec inositolum. Nitras kalicus non assimilatur. Arbutinum finditur (exiguum). Biotinae et pyridoxinae necessariae ad crescentiam. Maxima temperatura crescentiar: $35-36^{\circ}$.

Growth in YM broth: After 3 days at $25^{\circ}$, cells are nearly round or oval, $(2-5.5) \times(2.5-7) \mu$, and occur singly, in pairs, or in chains. Only a sediment is formed. After one month at $17^{\circ}$, trace of a ring is also formed.

Growth on YM agar: After one month at $17^{\circ}$, the streak culture is yellowish gray, flat, smooth, shining, soft, and has an entire margin.

Slide culture: No pseudomycelium is formed.

Fermentation: D-Glucose and trehalose (latent) are fermented. D-Galactose, saccharose, maltose, lactose, raffinose, melibiose, melezitose, inulin, and soluble starch are not fermented. 
Assimilation of carbon compounds: D-Glucose, saccharose, maltose, Lsorbose, trehalose, melezitose, D-xylose, D-ribose (latent), L-rhamnose (latent), ethanol, glycerol, adonitol, D-mannitol, D-sorbitol, $\alpha$-methyl-D-glucoside (latent), potassium gluconate, calcium 2-ketogluconate, succinic acid, and citric acid are assimilated. D-Galactose, lactose, cellobiose, melibiose, raffinose, inulin, soluble starch, L-arabinose, D-arabinose, erythritol, dulcitol, salicin, DL-lactic acid, and inositol are not assimilated.

Potassium nitrate is not utilized as the sole nitrogen source.

Arbutin is weakly splitted.

Gelatin is not liquefied.

Starch-like compounds are not produced.

Maximum growth temperature is $35-36^{\circ}$.

Biotin and pyridoxine are required at $25^{\circ}$.

Urease is not detected on Christensen's medium.

Source: Banana, food market, Tokyo, May 1962.

Of the five sugars commonly employed in yeast classification, this yeast ferments only D-glucose and assimilates D-glucose, saccharose, and maltose. These characteristics coincide with Torulopsis ernobii. Torulopsis ernobii, however, has a GC content of $36 \%$ (11) which is about $12 \%$ lower than that of Torulopsis musae (Table 1). Further, a considerable difference is observed between the standard description of Torulopsis ernobii (10) and Torulopsis musae. The specific epithet is derived from the Latin "musa" meaning "banana" from which this yeast was isolated. The strain AJ 4408 is the type strain of this species, and was deposited in the Institute for Fermentation, Osaka, as IFO 1582.

6). Trichosporon brassicae NAKASE sp. nov.

Strain: AJ 4833

In medio liquido cellulae rotundae, subovoideae aut ovoideae, $(3-7.5) \times$ (3.5-13) $\mu$. Pellicula formatur. Cultura in agaro subflava aut flavoalbida, nitida, glabra, mucosa, margine pilosa. Mycelium verum cum blastosporis et arthrosporis. Fermentatio nulla. In medio minerali D-glucosum, D-galactosum, saccharosum, maltosum, L-sorbosum, trehalosum, D-xylosum, L-arabinosum, D-ribosum, ethanolum, glycerolum, D-mannitolum (lente), D-sorbitolum (lente), potassium gluconatum, calcium gluconatum, acidum DL-lacticum, acidum succinicum, acidum citricum, inositolum assimilantur at non lactosum, cellobiosum, melibiosum, raffinosum, melezitosum, inulinum, amylum, D-arabinosum, L-rhamnosum, erythritolum, adonitolum, dulcitolum, $\alpha$-methyl-D-glucosidum, nec salicinum. Nitras kalicus non assimilatur. Arbutinum finditur (exiguum). Thiaminae necessariae ad crescentiam. Maxima temperatura crescentiar: $37-38^{\circ}$.

Growth in YM broth: After 3 days at $25^{\circ}$, yeast cells are mostly round to short oval, measuring $(3-7.5) \times(3.5-13) \mu$. Fragments of true mycelia which 


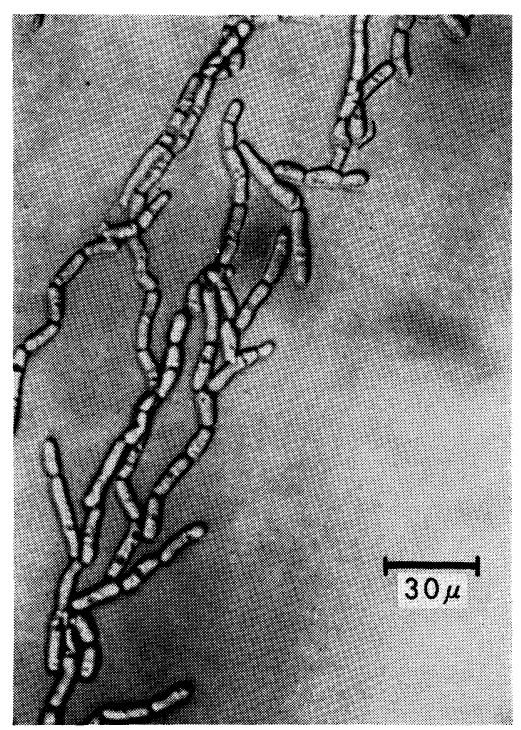

Fig. 3. True mycelia and arthrospores of Trichosporon brassicae AJ 4833 , slide culture on potato dextrose agar for 4 days at $25^{\circ}$.

are very long are observed. After one month at $17^{\circ}$, a thick, mucous and fragile pellicle is formed.

Growth on YM agar: After one month at $17^{\circ}$, the streak culture is pale yellow to grayish white, smooth, mucous, and shining. The margin is surrounded by mycelia.

Slide culture: True mycelia form abundantly. Arthropores often give rise to a zigzag formation.

Fermentation: Absent.

Assimilation of carbon compounds: D-Glucose, D-galactose, saccharose, maltose, L-sorbose, trehalose, D-xylose, L-arabinose, D-ribose, ethanol, glycerol, D-mannitol (latent), D-sorbitol (latent), potassium gluconate, calcium 2-ketogluconate, DL-lactic acid, succinic acid, citric acid, and inositol are assimilated. Lactose, cellobiose, melibiose, raffinose, melezitose, inulin, soluble starch, Darabinose, L-rhamnose, erythritol, adonitol, dulcitol, $\alpha$-methyl-D-glucoside, and salicin are not assimilated.

Potassium nitrate is not utilized as the sole nitrogen source.

Arbutin is weakly splitted.

Gelatin is not liquefied.

Starch-like compounds are not produced.

Maximum growth temperature is $37-38^{\circ}$.

Thiamine is required at $25^{\circ}$.

Urease activity: Strongly positive on Christensen's medium.

Source: Cabbage, food market in Tokyo, May 1962. 
This species lacks fermentative ability and assimilates D-glucose, D-galactose, saccharose, and maltose but not lactose or nitrate. These characteristics resemble those of Trichosporon yamanashiensis nom. nud. (12). However, this species lacks typical characteristics of Trichosporon yamanashiensis such as formation of snow white colony and production of strong aroma like fruit esters. According to GOTO (personal communication), Trichosporon yamanashiensis should be included in the genus Geotrichum. Trichosporon brassicae shows a high GC content (Table 1) and exhibits strong urease activity, and is assumed to be related to heterobasidiomycetes. The strain AJ 4833 is the type strain of this species, and was deposited in the Institute for Fermentation, Osaka, as IFO 1584.

The author thanks Dr. K. Komagata for his invaluable suggestion for the present work, and Dr. S. Goto for his communication on Trichosporon yamanashiensis. Many thanks are also due to Mrs. M. Shimmyo, Mrs. H. Shiobara, and Miss S. Miyazawa for their technical assistance.

\section{REFERENCES}

1) L.J. Wickerham, Taxonomy of Yeasts, U.S.D.A. Tech. Bull. No. 1029 (1951).

2) J. Lodder and N.J.W. Kreger-VAn RiJ, The Yeasts, a Taxonomic Study, NorthHolland Publ. Co., Amsterdam (1952).

3) K. Komagata and T. NAKaSE, Shokuhin Eiseigaku Zasshi, 8, 53 (1967).

4) H.P.R. SeEliger, J. Bacteriol., 72, 127 (1956).

5) T. Nakase and K. Komagata, J. Gen. Appl. Microbiol., 14, 345 (1968).

6) J. Marmur and P. Doty, J. Mol. Biol., 5, 109 (1962).

7) K. Yamada and K. Komagata, J. Gen. Appl. Microbiol., 16, 215 (1970).

8) N. van Uden and H. Buckley, Genus Candida Berkhout, In The Yeasts, a Taxonomic Study, ed. by J. Lodder, North-Holland Publ. Co., Amsterdam (1970).

9) T. Nakase and K. Komagata, J. Gen. Appl. Microbiol., 17, 259 (1971).

10) N. van Uden and M. Vidal-Leiria, Genus Torulopsis Berlese, In The Yeasts, a Taxonomic Study, ed. by J. Lodder, North-Holland Publ. Co., Amsterdam (1970).

11) T. Nakase and K. Komagata, J. Gen. Appl. Microbiol., 17, 161 (1971).

12) I. YokотsukA and S. Goto, Nippon Nogeikagaku Kaishi, 29, 132 (1955). 